УДК 377.8.014.5

DOI:

Юлія Петровська, кандидат економічних наук, доцент кафедри менеджменту та міжнародних економічних відносин Навчально-наукового інституту управління, економіки та природокористування

Таврійського національного університету імені В.I. Вернадського

Слизавета Зайчук, магістрант кафедри менеджменту та міжнародних економічних відносин Навчально-наукового інституту управління, економіки та природокористування Таврійського наиіонального університету імені В.I. Вернадського

\title{
СУЧАСНІ ПІДХОДИ ДО СТРАТЕГІЧНОГО ПЛАНУВАННЯ У КОЛЕДЖІ
}

У статті розглянуто підходи до визначення особливостей стратегічного планування розвитку коледжу як закладу фахової передвищої освіти в сучасних умовах реформування освітньої галузі. 3 'ясовано сутність та зміст стратегічного планування розвитку закладу коледжу як закладу фахової передвищої освіти. Розглянуто основні функиії та завдання, а також визначено етапи планування. Авторами досліджено досвід стратегічного планування розвитку закладів вищої освіти Украӥни.

Ключові слова: заклад вищої освіти; заклад фахової передвищої освіти; стратегічне планування; розвиток; цілі; задачі; етапи.

Табл. 3. Рис. 2. Літ. 11.

Yuliya Petrovska, Ph.D.(Economic Sciences), Associate Professor of the Management and International Economic Relations Department

Educational and Scientific Institute of Management, Economics and Environmental Management Tavriya Volodymyr Vernadskiy National University

Yelyzaveta Zaychuk, Master Student of the Management and International Economic Relations Department Educational and Scientific Institute of Management, Economics and Environmental Management Tavriya Volodymyr Vernadskiy National University

\section{THE CONTEMPORARY APPROACHES TO STRATEGIC PLANNING AT A COLLEGE}

The approaches to defining the features of strategic planning of the college development as professional prehigher education in the current conditions of the educational reform are considered in the article. Starting from 2020, Ukrainian colleges and technical schools will train specialists for the proficiency level Junior bachelor and will no longer recruit enrollees for an educational-proficiency level Junior Specialist, as provided by the Law of Ukraine "On Professional Higher Education". Therefore, the administrations of colleges are determining the strategy of the development and management of educational institutions in accordance with the legislation of Ukraine. The authors study the essence and content of planning for the college development, identify the main functions and tasks, identify the main stages and methodological approaches of planning for the development, and activities of colleges on the basis of strategic management.

The authors point out that the choice of strategy as a model of action, in which the future must necessarily be better than the past and the plan itself determines specific future actions to achieve the set goals is the basis of the approach for the strategic planning at the college, as professional pre-higher education. Both the external and internal capabilities of the college are taken into account while developing the plan.

The authors outline the main perspectives, strategic goals of the college, and generalized indicators for planning college development. The content of the strategic plan of the college is reviewed and it is emphasized that it should correspond to the defined mission and directions of the accepted policy of the professional pre-higher education. This plan is decomposed into an annual plan to implement the strategy. The authors consider the development of a number of targeted programs facilitates the successful implementation of the strategic plan of the college.

This approach transfer the strategic visions and measurable indexes that can be brought to all levels of the college management system and resource allocation, as well as providing feedback, training, and ongoing monitoring of the strategy implementation. In this case, the college's activities will be more transparent and manageable.

Keywords: the institution of higher education; Professional pre-higher education; strategic planning, development; goals; tasks; stages.

П остановка проблеми. Процеси реформування у вітчизняній освіті пов'язані, насамперед, з потребою вирішення системних проблем, які накопичились упродовж усього періоду існування незалежної України, коли освітня сфера, з одного боку, активно впроваджувала інновації, а з іншого, за інерцією," зберігала багато ознак та характеристик 
радянської системи [3]. Сьогодні мова йде про створення в Україні такої системи освіти, яка була здатна забезпечити якість знань, давала адекватну відповідь на вимоги соціокультурних реалій, була тотожна європейським та світовим стандартам, сприяла розвитку держави у всіх вимірах.

Модернізація системи вітчизняної освіти неможлива без прогнозу і планування її розвитку. Що стосується прогнозів розвитку економіки України, в тому числі таких важливих показників як ВВП, обсяги промислової та сільськогосподарської продукції, то їм присвячено багато досліджень, публікацій та програм. Однак, серед цих досліджень майже відсутні прогнози розвитку і використання потенціалу такого виду економічної діяльності як вища освіта [5]. До складу вищої освіти станом на сьогоднішній день віднесені коледжі, які надають вищу освіту за освітньокваліфікаційним рівнем “молодший спеціаліст”. Згідно Закону України "Про фахову передвищу освіту” з 2020 року освітньно-кваліфікаційний рівень "молодший спеціаліст" буде виведено 3 системи вищої освіти і уведено ступінь “молодший бакалавр” або “фаховий молодший бакалавр”. Це залежатиме від того, який шлях розвитку обере коледж. Таким чином, перед закладами освіти, які здійснюють підготовку молодших спеціалістів (вищі навчальні заклади I - II рівнів акредитації), постала задача переосмислення своєї діяльність та позиціонування в системі освіти України, визначення шляхів для подальшого розвитку 3 урахуванням власного бачення та національного законодавства.

Аналіз останніх досліджень та публікацій. Системна реформа сфери освіти вимагає наукового підгрунтя та усебічного вивчення умов iї реалізації. Вчені надають практикам осмислення трансформаційних процесів у освітній сфері, пропонують підходи до реформування системи освіти, це знаходить відображене у наукових роботах В. Андрущенка, В. Кременя, В. Лугового, В. Огнев'юка. Підходи, засновані на ідеях стратегічного управління освітнім закладом, розкриті в роботах українських і зарубіжних дослідників Б. Гершунського, Л. Даниленко, Г. Сльнікової, М. Клименюка, І. Качарян, Л. Карамушки, С. Нетрошвілі, О. Пометун, Н. Островерхової, В. Маслова, М. Поташника, ін. У той же час названими роботами не вичерпується дослідження даної проблеми.

Варто враховувати, що суспільство вступило у постіндустріальну епоху, набуло рис інформаційного, для якого виробництво нового знання є ключовим видом діяльності, а провідними чинниками розвитку виступають наука та освіта. Розвиток і планування такої системи освіти можливе за умов іiї стратегічного бачення і управління.

Метою статті $€$ визначення особливостей стратегічного планування розвитку коледжів в умовах реформування. 32020 року українські коледжі та технікуми почнуть надавати фахову передвищу освіту: вони готуватимуть спеціалістів за ступенем фахового молодшого бакалавра i більше не набиратимуть вступників на навчання за освітньо-кваліфікаційним рівнем молодшого спеціаліста як передбачено Законом України “Про фахову передвищу освіту”. Тому коледжі, як заклади фахової передвищої освіти, у відповідності до вимог законодавства країни, визначають сьогодні стратегію розвитку і управління закладом освіти. Для досягнення мети в роботі поставлені для розв'язку завдання щодо визначення сутності та змісту стратегічного планування, установлення основних функцій та завдань, виявлення основних етапів та методичних підходів до стратегічного планування розвитку і діяльності коледжів в освітньому просторі країни.

Виклад основного матеріалу. Сьогодення вимагає від української вищої школи модернізації системи освіти та нових підходів до організації управління у тому числі. Спробою знайти відповідь на питання про те, як управляти в умовах, які не цілком прозорі, змінюються i залежать від безлічі факторів, може "стати" стратегічний менеджмент, як комплекс стратегічних рішень, що визначають довгостроковий розвиток закладів вищої освіти, та конкретних дій, що забезпечують швидке реагування на зміни зовнішньої кон'юнктури [5].

В системі стратегічного менеджменту чільне місце посідає планування, яке охоплює широкий спектр питань стратегічного менеджменту: розробка концепцій організації, аналіз перспектив розвитку, аналіз стану структур, конкурентне середовище, формулювання маркетингової стратегії, аналіз секторів ринку освітніх послуг, відкриття стратегічних перспективних закладів і підприємств, ін. [4]. В наукових колах на даний час не існує спільної думки і погляду на сутність стратегічного планування у закладах вищої освіти, що своєю чергою ускладнює впровадження в практику планування на основі стратегічного менеджменту. Необхідно також підкреслити, що існують суттєві відмінності стратегічного і перспективного планування. В основі перспективного планування лежить існуючий стан справ, а майбутнє представляється як його еволюційна зміна, що не торкається принципових основ організації. 


\section{СУЧАСНІ ПДХОДИ ДО СТРАТЕГІЧНОГО ПЛАНУВАННЯ У КОЛЕДЖІ}

Науковець Р. Акофф вважає, що планування це розроблення бажаного майбутнього, а також способів, якими його можна було б реалізувати [10].

Вчений К. Рідінг стверджує, що сутність стратегічного планування полягає у визначенні вектора розвитку підприємства, який підтримує як його керівництво, так і співробітників [8].

В основі підходу до стратегічного планування у коледжі, як закладі фахової передвищої освіти, лежить вибір стратегії, як моделі дій, при якій майбутнє обов'язково має бути кращим за минуле, а сам план - визначає конкретні майбутні дії для досягнення поставлених цілей. Під час розробки плану до уваги беруться як зовнішні, так і внутрішні можливості коледжу. Планування, засноване на засадах стратегічного менеджменту, оцінює перспективи, виявляє можливості та загрози зовнішнього середовища, сильні та слабкі сторони внутрішнього середовища, а також аналізує зміни конкурентної позиції закладу освіти на ринку. При цьому головні передумови успішної діяльності перебувають назовні закладу освіти, тобто його успіх пов'язується $з$ тим, наскільки заклад освіти швидко адаптується до умов і вимог навколишнього середовища: економічного, науково-технічного, міжнародного тощо.

Окрім того, стратегічне планування розвитку коледжу представляє собою систему управління, яка заснована на механізмі узгодження поточних рішень - тактичних i оперативних - iз стратегічними, а також із механізмом коригування і контролю за реалізацією обраної стратегії розвитку [9].

Наукові дослідженні і практичний досвід свідчать про те, що необхідність розробляти стратегію з'являється при дефіциті ресурсів. У разі, якщо керівництво закладу вищої освіти має у розпорядженні достатньо ресурсів, щоб вирішити потрібне йому завдання, воно вирішує його, не розробляючи будь-якої спеціальної стратегії. Інша справа, коли ресурсів недостатньо - тоді, перш ніж почати діяти, необхідно аналізувати різні варіанти, оцінювати баланси витрат, ризиків, ресурси, визначати критичні точки, які можуть негативно вплинути на вирішення завдань, ін. [2].

У цих умовах точний вибір пріоритетів $\mathrm{i}$ напрямів діяльності, які можуть бути реально забезпечені наявними ресурсами, можливостями (здібностями), набуває життєвоважливого значення.

Для визначення стратегії, що відображає філософію та перспективи розвитку і перетворення закладу освіти у стійку, здатну до саморозвитку систему, що буде активно взаємодіяти із зовнішнім середовищем, необхідно розв'язати завдання, які у своєму рішенні сприятимуть зміцненню взаємодії наукової та педагогічної спільноти, матимуть вплив на комплексний розвиток та зміцнення економіки; визначать шляхи мобілізації внутрішніх інтелектуальних, матеріально-технічних, творчих ресурсів; винайдуть механізми залучення зовнішніх фінансових, матеріальних і гуманітарних ресурсів для розвиткузакладу фахової передвищої освіти та формування його привабливого іміджу.

Основою успішного стратегічного планування $\epsilon$ правильно визначені цілі закладу вищої освіти, оскільки тільки знання цілей дозволить намітити шляхи і засоби їх реалізації (табл. 1).

Стратегічне планування на основі визначених цілей передбачає якісні докорінні зміни місії коледжу в зв'язку з мінливими умовами i направлено на використання конкурентних переваг навчального закладу для підвищення його життєздатності.

На основі дослідження наукових джерел та зважаючи на сучасну практику діяльності закладів вищої освіти, можна окреслити такі основні функції та задачі стратегічного планування розвитку коледжу (табл. 2).

Окрім того, стратегічне планування має особливості, що виявляються у основних напрямках діяльності закладу, розрахованих на довгострокову перспективу, погляді на коледж як на єдине ціле, основною метою стратегічного планування є формування потенціалу майбутнього успіху організації.

Важливо також підкреслити, що для ефективного планування діяльності закладу вищої освіти на основі стратегічного менеджменту необхідні основні п'ять компонентів: кадри, фінанси, час, попередня підготовка, структурований процес.

На підставі досліджених наукових джерел ми вважаємо, що планування на основі стратегічного менеджменту і його реалізація коледжі, як закладі фахової передвищої освіти (ЗФПО) як суб'єкті ринку, може грунтуватися на певній методиці, що включає:

1. Аналіз зовнішнього середовища ЗФПО, прогноз розвитку.

2. Аналіз внутрішнього середовища ЗФПО.

3. Аналіз стану та прогноз розвитку позиції ЗФПО на ринку освітніх послуг.

4. Розробка місії і концепції стратегічного розвитку ЗФПО.

5. Розробка основних стратегій ЗФПО за основними напрямками діяльності.

6. Розробка основних компонентів маркетингу. 
Таблиця 1.

Цілі стратегічного планування розвитку коледжу

\begin{tabular}{|c|c|}
\hline $\begin{array}{c}\text { Цілі (основні) стратегічного } \\
\text { планування }\end{array}$ & Характеристика оріснтирів планування \\
\hline Розподіл ресурсів & $\begin{array}{l}\text { Процес передбачає розподіл обмежених організаційних } \\
\text { ресурсів, таких як фінанси, викладацький склад, матеріально- } \\
\text { технічні, управлінські кадри, репутація і наявний досвід } \\
\text { освітньої діяльності закладу вищої освіти }\end{array}$ \\
\hline $\begin{array}{l}\text { Адаптація до зовнішнього } \\
\text { середовища }\end{array}$ & $\begin{array}{l}\text { Заклад вищої освіти повинен вміти швидко адаптуватися як до } \\
\text { зовнішніх сприятливих можливостей, так і до можливих загроз, } \\
\text { Передбачити варіанти сценаріїв адаптації та ефективного } \\
\text { пристосування стратегії до умов, що виникають у зовнішньому } \\
\text { середовищі }\end{array}$ \\
\hline $\begin{array}{l}\text { Координація внутрішніх процесів } \\
\text { ЗВО }\end{array}$ & $\begin{array}{l}\text { Включає координацію стратегічної діяльності для врахування } \\
\text { сильних і слабких сторін закладу вищої освіти } 3 \text { метою } \\
\text { досягнення } \\
\text { ефективної інтеграції внутрішніх процесів, які є } \\
\text { невід’ємною складовою успішної діяльності. }\end{array}$ \\
\hline $\begin{array}{l}\text { Усвідомлення колективом ЗВО } \\
\text { визначених стратегій }\end{array}$ & $\begin{array}{l}\text { Така діяльність передбачає формування можливостей вчитися на } \\
\text { наявному досвіді. } \\
\text { Правильно обирати та коригувати свій стратегічний напрямок } \\
\text { розвитку, прогнозувати майбутнє та підвищити професіоналізм } \\
\text { у сфері стратегічного управління }\end{array}$ \\
\hline
\end{tabular}

7. Проектування організаційної структури ЗФПО, адекватної поставленим цілям $[5 ; 6 ; 7 ; 8$ iн.].

Разом $з$ тим, важливо підкреслити, що при підході до розробки плану, слід враховувати не лише можливості, а й обмеження які $є$ і можуть бути у управлінської команди коледжу, зацікавленої у використанні технологій стратегічного планування. Інструментарій, який може бути використаний для цього, досить обмежений : SWOT-аналіз, бенчмаркетинг, GAP - аналіз.

Використання SWOT-аналізу для визначення можливостей та обмежень технології стратегічного планування дозволяє отримати наступні матриці: “сильні і слабкі сторони ЗВО в стратегічному плануванні” та “можливості і загрози застосування технології стратегічного планування".

3 огляду на названі позиції, стратегічне планування у коледжі, як закладі фахової передвищої освіти, це - процес послідовного вирішення стратегічних проблем, на кожному етапі якого застосовуються специфічні методи.

Базова модель стратегічного планування у коледжі може бути побудована на основі логіки, запропонованої Grang-Chol CHANG (рис. 1.) [11].

Актуальності і доцільності такій моделі можуть додати встановлені збалансовані показники ефективності та передбачення результатів, до яких прагне коледж, а також поєднання цілей і дій по їх досягненню
Дана модель, на наш погляд, досить гнучка та ефективна для поєднання внутрішніх i зовнішніх аспектів планування. Базовими принципами ії̈ побудови виступають неперервність, гнучкість (адаптивність), наявність вимірних показників (фінансових і нефінансових), врахування інтересів усіх зацікавлених сторін. Що свою чергою дає змогу визначити стратегію, на основі якої заклад освіти сформує місію і політику для подальшого розвитку і діяльності на ринку освітніх послуг.

Під час роботи по розробці стратегічного плану, коледжу необхідно, як уже зазначено вище, проаналізувати і визначити запити середовища, врахувати потреби основних груп впливу (стейкхолдерів) на стан і розвиток навчального закладу, сформулювати цілі, проаналізувати ресурси.

Для цього, на наш погляд, необхідно здійснити ряд кроків. Одним із перших, $є$ аналіз базових компетенцій і формулювання місії, далі-необхідно провести аналіз зовнішнього середовища (SWOT) для визначення стратегіï, як напрямку дій для досягнення поставлених цілей. Наступним кроком має бути уточнення стратегії (на основі проведення галузевого аналізу), а потім можливо розробити стратегічну карту, як покроковий процес досягнень (рис. 2).

На основі стратегічної карти можна формувати основні цільові показники, які систематизуються у вигляді плану (табл.3.) У таблиці 3 показані основні перспективні та 
Таблиця 2.

Основні функції та задачі стратегічного планування розвитку коледжу

\begin{tabular}{|c|c|c|c|c|}
\hline \multicolumn{5}{|c|}{ Основні функції стратегічного планування розвитку коледжу } \\
\hline $\begin{array}{c}\text { Визначення } \\
\text { стратегії }\end{array}$ & $\begin{array}{c}\text { Планування дій } \\
\text { для реалізації } \\
\text { стратегічних } \\
\text { завдань }\end{array}$ & $\begin{array}{c}\text { Оцінка } \\
\text { потенційних } \\
\text { можливостей }\end{array}$ & $\begin{array}{c}\text { Моніторинг ресурсів } \\
\text { для реалізації } \\
\text { стратегії }\end{array}$ & $\begin{array}{c}\text { Контроль за } \\
\text { процесом } \\
\text { виконання } \\
\text { стратегії }\end{array}$ \\
\hline \multicolumn{5}{|c|}{ Задачі стратегічного планування розвитку коледжу } \\
\hline $\begin{array}{l}\text { Аналіз } \\
\text { перспектив і } \\
\text { стану } \\
\text { демографічних та } \\
\text { географічних } \\
\text { ринків; ринку } \\
\text { освітніх послуг } \\
\text { Установлення } \\
\text { співвідношення } \\
\text { частки ринків, } \\
\text { яку займає } \\
\text { коледж і } \\
\text { можливостей } \\
\text { їх збільшення. } \\
\text { Виявлення } \\
\text { першочергових } \\
\text { цілей за } \\
\text { результатами } \\
\text { маркетингу } \\
\text { Розробка дерева } \\
\text { цілей з реалізації } \\
\text { стратегічних } \\
\text { напрямків } \\
\text { Оцінка } \\
\text { сприйнятли } \\
\text { вості ринку до } \\
\text { освітніх послуг } \\
\text { У становлення } \\
\text { вимог до } \\
\text { кадрового складу }\end{array}$ & $\begin{array}{l}\text { Розробка } \\
\text { цільових програм } \\
\text { з реалізації } \\
\text { стратегіч- } \\
\text { них цілей } \\
\text { Встановлення } \\
\text { цільвоих } \\
\text { показників. } \\
\text { Аналіз } \\
\text { можливостей } \\
\text { диверсифікації } \\
\text { освітньої } \\
\text { діяльності } \\
\text { Формування } \\
\text { бюджету }\end{array}$ & $\begin{array}{l}\text { Оцінка } \\
\text { рівня готовності і } \\
\text { здатності } \\
\text { структур коледжу } \\
\text { до реалізації } \\
\text { стратегії } \\
\text { Оцінка } \\
\text { конкурентно- } \\
\text { здатності освітніх } \\
\text { послуг. } \\
\text { Вибір } \\
\text { маркетингових } \\
\text { програм } \\
\text { Аналіз } \\
\text { очікуваних } \\
\text { поточних і } \\
\text { капітальних } \\
\text { витрат на } \\
\text { стратегічні } \\
\text { цілі } \\
\text { Оцінка факторів } \\
\text { зовнішнього } \\
\text { середовища }\end{array}$ & $\begin{array}{l}\text { Аналіз стану наявних } \\
\text { ресурсів коледжу. } \\
\text { Формування вимог } \\
\text { до якості та кількості } \\
\text { необхідних ресурсів. } \\
\text { Визначення джерел } \\
\text { фінансування } \\
\text { Формування планів } \\
\text { залучення } \\
\text { додаткових } \\
\text { ресурсів }\end{array}$ & $\begin{array}{l}\text { Постійцний } \\
\text { моніторинг } \\
\text { процесу } \\
\text { реалізації } \\
\text { стратегічних } \\
\text { планів. } \\
\text { Завчасне } \\
\text { визначення } \\
\text { загроз, } \\
\text { виявлення } \\
\text { помилки та } \\
\text { відхилення від } \\
\text { прийнятих } \\
\text { стратегій і } \\
\text { політики } \\
\text { коледжу }\end{array}$ \\
\hline
\end{tabular}

(таблиця розроблена авторами на основі п. 4, 5, 7, 8, 9)

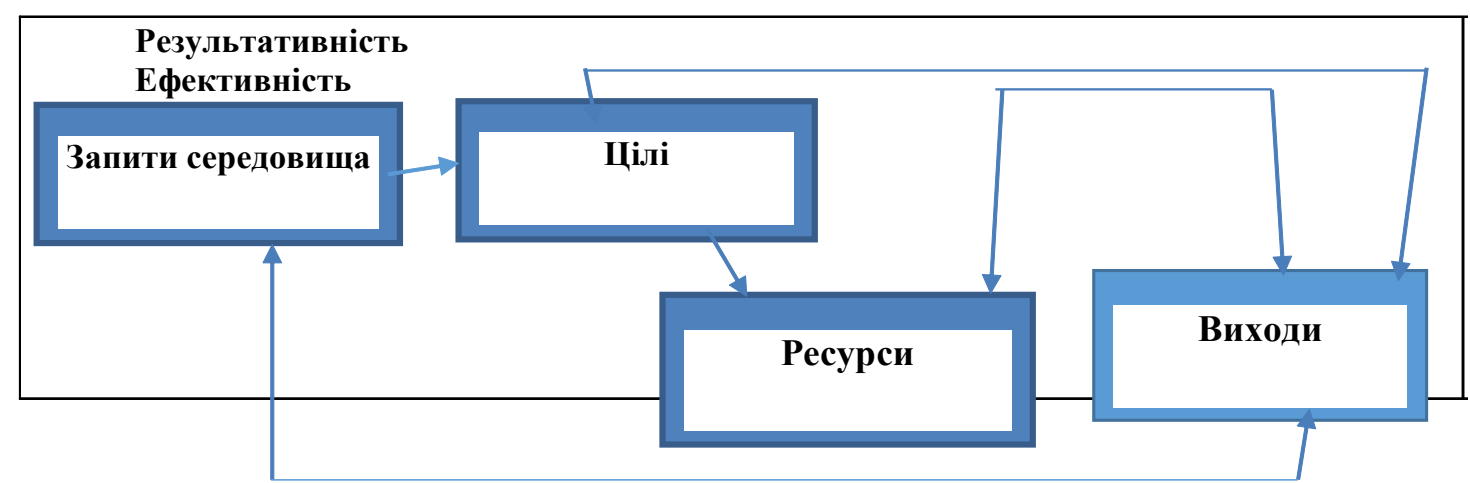

Рис. 1. Модель стратегічного планування коледжу (запропонована Grang-Chol CHANG)

стратегічні задачі коледжу та узагальнені показники для планування розвитку коледжу 3 метою вирішення стратегічних завдань, що стоять у процесі реформування освіти перед коледжами як закладами вищої та фахової передвищої освіти, на сучасному етапі.

Зміст самого стратегічного плану коледжу має відповідати визначеній місії та напрямками 


\begin{tabular}{|c|c|}
\hline Складові стратегічної карти коледжу & $\begin{array}{c}\text { Ключові питання складових карти } \\
\text { коледжу }\end{array}$ \\
\hline Суспільна складова & Яке ми складаємо враження у разі успіху? \\
\hline Фінансова складова & $\begin{array}{c}\text { Яких результатів ми досягнемо у } \\
\text { разі успіху? }\end{array}$ \\
\hline Клієнтська складова & $\begin{array}{l}\text { Яке враження клієнтів про нас, } \\
\text { для досягнення нашого успіху? }\end{array}$ \\
\hline Внутрішні процес & $\begin{array}{c}\text { Які процеси необхідно вдосконалювати } \\
\text { для задоволення запитів клієнтів ? }\end{array}$ \\
\hline $\begin{array}{c}\text { Складові } \\
\text { освітнього значення та зростання }\end{array}$ & $\begin{array}{c}\text { В якому напрямку рухатись для } \\
\text { реалізації місії ? }\end{array}$ \\
\hline
\end{tabular}

Рис. 2. Модель стратегічної карти коледжу

прийнятої політики закладу фахової передвищої освіти. Для реалізації стратегії даний план декомпонується до годового плану. Успішному виконанню стратегічного плану коледжу сприяє розробка ряду цільових програм.

Такий підхід дає змогу переводити бачення стратегії і вимірні показники, які можна довести до всіх рівнів системи управління в коледжі та до розподілу ресурсів, а також здійснити зворотній зв'язок, провести навчання та поточний моніторинг реалізації стратегії. У такому випадку діяльність коледжу буде більш прозорою і керованою.

При стратегічному планування діяльності і розвитку коледжу важливою умовою, як ми уже зазначили, необхідно враховувати позиції, вимоги, інтереси сторін (стейкхолдерів), що мають вплив і зацікавлені у розвитку коледжу є важливою умовою.

До основної груп впливу на перспективу розвитку і споживання освітніх послуг коледжу слід віднести молодих людей, у віці від 15 до 26 років, які мають середню базову або повну загальну освіту, а також професійно-технічну освіту. Головною мотиваційною умовою навчання у коледжі у них виступає бажання задовольнити свої особистісні потреби в поглибленні і розширенні освіти, підвищити рівень своєї кваліфікації і освіти 3 метою зміни соціального статусу в суспільстві і, головним чином, в підвищенні свого рівня конкурентоспроможності на ринках праці.

Основною економічною характеристикою цієї групи впливу на розвиток і діяльність коледжу на ринку освітніх послуг виступає, невисокий “ майже середній рівень доходів сім’ї або власних доходів, що і пояснює бажання молодих людей отримати економічну самостійність від сім'ї і підвищити свій соціальний статус за нетривалий період навчання.

Наступною групою, яка має вплив і виявляє зацікавленість у розвитку коледжів, як закладів фахової передвищої освіти, є представники ринків праці - підприємства, установи, організації та інші суб'єкти господарювання, які виступають споживачами випускників-фахівців коледжу і мають значний дефіцит спеціалістів середньої ланки виробництв.

Таблиця 3.

Перспективи, стратегічні завдання та показники розвитку коледжу

\begin{tabular}{|c|c|c|}
\hline Перспективи & $\begin{array}{c}\text { Стратегічні } \\
\text { задачі }\end{array}$ & Показники \\
\hline $\begin{array}{l}\text { Суспільне } \\
\text { значення }\end{array}$ & $\begin{array}{l}\text { Развиток } \\
\text { коледжу у } \\
\text { системі фахової } \\
\text { передвищої } \\
\text { освіти } \\
\text { Забезпечення } \\
\text { якості освітніх } \\
\text { послуг }\end{array}$ & $\begin{array}{l}\text { - наявність механізмів інноваційної діяльності коледжу у } \\
\text { відповідності до вимог Закону “Про фахову передвищу } \\
\text { освіту” } \\
\text { - співпраця з вітчизняними та зарубіжними закладами } \\
\text { освіти; } \\
\text { - питома вага чисельності вступників до коледжу на основі } \\
\text { ЗНО, } \\
\text { - відсоток студентів, що склали ДПА у формі ЗНО, ін. }\end{array}$ \\
\hline Фінанси & $\begin{array}{l}\text { Удосконалення } \\
\text { економічних } \\
\text { механізмів }\end{array}$ & $\begin{array}{l}\text {-поза бюджетні кошти у розрахунку на одного штатного } \\
\text { викладача, тис. грн.; } \\
\text { - бюджетні кошти, виділені на одного студента денної форми } \\
\text { навчання, тис.грн. } \\
\text { - забезпечення навчально-лабораторними площами у } \\
\text { відповідності до нормативу на одного студента \% }\end{array}$ \\
\hline
\end{tabular}

Молодь і ринок №11 (178), 2019 
Продовження таблиці 3.

\begin{tabular}{|c|c|c|}
\hline Клієнти & $\begin{array}{l}\text { Задоволення } \\
\text { потреб споживачів }\end{array}$ & $\begin{array}{l}\text {-питома вага чисельності працевлаштованих упродовж } \\
\text { першого року випускників денної форми навчання ; } \\
\text {-конкурс при вступі до коледжу (кількість осіб на місце); } \\
\text {-співвідношення вартості (річна ) навчання до середньої } \\
\text { галузевої , \% }\end{array}$ \\
\hline Внутрішні процеси & $\begin{array}{l}\text { Удосконалення } \\
\text { змісту та } \\
\text { технологій освіти }\end{array}$ & $\begin{array}{l}\text { - якість знань, в т.ч. випускників (середний бал); } \\
\text { - середньорічний показник контингенту студентів, що } \\
\text { навчаються за освітньо-професійними програмами; } \\
\text {-слухачів, що навчаються за програмами професійної } \\
\text { перепідготовки та (або) підвищення кваліфікації (осіб.); } \\
\text { - відсоток навчальних дисциплін основних освітньо- } \\
\text { професійних програм, що забезпечені навчально- } \\
\text { методичними комплексами; } \\
\text {-питома вага спеціальностей професійної підготовки, які } \\
\text { здійснюються на основі акредитованих освітньо- } \\
\text { професійних програм; } \\
\text {-питома вага спеціальностей по яким впроваджені } \\
\text { сучасні методи навчання (індивідуальне, дистанційне, } \\
\text { інше); } \\
\text {-питома вага вступників, які закінчили курси підготовки } \\
\text { до вступу до коледжу; } \\
\text { - зміна чисельності студентів усіх форм навчання, \%; } \\
\text { - зміна числа спеціальностей і спеціалізацій }\end{array}$ \\
\hline $\begin{array}{l}\text { Інфраструктура / } \\
\text { (працівники) }\end{array}$ & $\begin{array}{l}\text { Підвищення } \\
\text { ефективності } \\
\text { управління }\end{array}$ & $\begin{array}{l}\text { - зміна чисельності викладацького складу, який працює } \\
\text { на повну ставку на штатній основі; } \\
\text { - співвідношення середньої заробітної плати } \\
\text { викладацького складу по відношенню до середньої } \\
\text { заробітної плати у галузі; } \\
\text { - відсоток викладачів з вченим ступенем або вченим } \\
\text { званням; } \\
\text { - } \quad \text { відсоток викладачів, що мають вищу кваліфікаційну } \\
\text { категорію та звання; } \\
\text {-зростання показника автоматизованих робочих місць; } \\
\text {-доля керівників і спеціалістів, що пройшли } \\
\text { перепідготовку з проблем і методів управління в системі } \\
\text { освітии у відповідності до встановлених вимог; ін. }\end{array}$ \\
\hline
\end{tabular}

(таблиця розроблена авторами на основі п.4, 5, 6, 7, 8,)

До групи впливу на стратегію розвитку коледжу відноситься і суспільство, інтереси якого проявляються, на нашу думку, двояко. 3 одного боку, суспільство зацікавлене в підготовці фахівців, що мають досить високий соціальний статус, а також середній рівень доходів та необхідний соціально-культурний і освітній рівень. Крім того, випускники коледжів виступають досить стабільною групою суспільства, яка здатна брати участь в процесах виробництва валового національного продукту в різних галузях народного господарства та управління цими процесами.

3 іншого боку, суспільство на даний час скорочує обсяги фінансування 3 державного бюджету. Сьогодні видатки освіти фактично фінансуються за “залишковим принципом”, тобто кошти на покриття цих видатків виділяються в останню чергу і в обсягах, які “залишилися” після покриття інших необхідних державних видатків.
За даними аналітичного центру CEDOS в Україні видатки на освітню галузь складали такий відсоток ВВП: у 2016 p. $-3,1 \%$, в $2017-18$ pp. $-3,6 \%$, в 2019 p. - 4.6\%. I як наслідок, державою встановлюється досить обмежений перелік предметних статей кошторису витрат бюджету на утримання коледжів.

Підприємства і організації - споживачі освітніх послуг коледжу, обмежують свою участь у підготовці спеціалістів наданням можливості проходження технологічної та переддипломної практик.

Основними складовими діяльності коледжу, як закладу фахової передвищої освіти, є i залишається освітній, науково-дослідний, і консультаційний, навчально-методичний, виховний процес. Отже, стратегічне планування має враховувати місце і роль кожного з процесів, визначати обсяги необхідних ресурсів, що забезпечують ці процеси. Особлива увага має зосереджуватись на кадровому забезпеченні. 
В ході стратегічного планування діяльності кожний коледж, як заклад фахової передвищої освіти, планує зайняти певну позицію на ринку освітніх послуг. Позиціонування будь-якої організації на ринку у відповідності до теорією класичного маркетингу - це процес визначення сукупності характеристик організації, які вигідно відрізняють іiі від конкурентів [9]. Тому стратегічне планування коледжу має відповідати новим вимогам і умовам функціонування ринку освітніх послуг, а його ринкова позиція повинна формуватись 3 урахуванням реальних конкурентних переваг.

Висновок. Стратегічне планування розвитку коледжу фахової передвищої освіти, спрямовує діяльність закладу на управління змінами 3 майбутнього у сьогодення та здатне на відповідь про шляхи досягнення поставлених цілей.

Стратегічне планування можна охарактеризувати як процес визначення і постановки стратегічних цілей і розробки стратегічного плану їх досягнення з урахуванням обраної стратегії. Головною метою стратегічного планування розвитку і діяльності коледжу є формування потенціалу майбутнього успіху організації для перетворення закладу у стійку, здатну до саморозвитку систему, що буде активно взаємодіяти із зовнішнім середовищем.

Основними складовими стратегічного планування $є$ : системний аналіз внутрішнього i зовнішнього середовища, вибір стратегічної мети, визначення стратегії досягнення поставленої мети, розробка стратегічного плану реалізації поставлених цілей.

Стратегічний план, на відміну від стратегії, передбачає послідовність певних кроків та дій, інтегрованих у просторі і часі, що приводять до зміни поточного становища на бажане.

Для коледжів, які сьогодні стоять на шляху розвитку як заклади фахової передвищої освіти, стратегічне планування дозволяє достойно зустріти виклики конкурентів, підготуватись до нових умов функціонування ринку освітніх послуг, стати інструментом координації зусиль закладів освіти із зовнішнім середовищем.

Окрім того, стратегічне планування має посісти чільне місце серед технологій управління коледжами як закладами фахової передвищої освіти.

\section{ЛІТЕРАТУРА}

1. Ансофф И. Стратегическое управление. сокр. пер. сангл. ; науч. ред. иавт. предисл. Л.И. Евенко. Москва, 1989. 519 с.

2. Балобанов, А.Е., Клюев А. К. Стратегическое планирование развития университета.
Университетское управление: практика и анализ, 2002. №2 (21). C. 18-27.

3. Братко М.В. Підготовка фахівців у коледжах:сучасні виміри та перспективи. Педагогічна освіта: теорія і практика: зб. наук. пр. Київ. ун-т ім. Бориса Грінченка. Київ, 2016. №25, Психологія. Педагогіка. 144 с. С.57-64.

4. Гордієнко П. Стратегічний аналіз : навч. посіб. Київ, 2006. 404 с.

5. Клименюк М.М., I.С.Качарян. Стратегія управління вищим навчальним закладом в сучасних умовах. Київ, 2011. 192 с.

6. Лесечко М.Д., Рудницька Р.М. Стратегічне планування: навчальний посібник. Львів, 2004. 76 с.

7. Натрошвілі С.Г. Стратегічне управління вищим навчальним закладом: теорія, методологія, практика: монографія. Київ, 2015. 326 с.

8. Ридинг К. Стратегическое бизнес-планирование: Динамическая система повышения эффективности и обеспечения конкурентного преимущества. под ред. И.А. Войтюк, пер. с англ. Днепропетровск, $2005.384 \mathrm{c}$.

9. Свистович М.Б. Сутність і основні поняття стратегічного планування. URL: http:// academy.gov.ua/ej/ej18/PDF/06.pdf

10. Ackoff R.Concept of Corporate Planning. New York:Wiley,1970. P.1.

11. Grang-Chol CHANG Strategic Planning in Education:Some Concept and Methods Vendredi 4 juillet 2008. URL: http://www.iiep.unesco.org/

\section{REFERENCES}

1. Ansoff, I. (1989). Strategicheskoe upravlenie [Strategic management]. (Ed.). L. I. Yevenko. Moscov, 519 p. [in Russian].

2. Balobanov, A.Ye. \& Klyuev, A. K. (2002). Strategicheskoe planirovanie razvitiya universiteta [Strategic University Development Planning]. University Management: Practice and Analysis.No.2 (21), pp. 18-27. [in Russian].

3. Bratko, M.V. (2016). Pidhotovka fakhivtsiv u koledzhakh:suchasni vymiry ta perspektyvy [Strategic University Development Planning]. Teacher Education: Theory and Practice: Coll. of Scientific works, Kyiv Borys Hrinchenko University. Kyiv, No. 25, Psychology, Pedagogy. 144 p. pp.5764. [in Ukrainian].

4. Hordiienko,P.(2006). Stratehichnyi analiz : navch. posib. [Strategic Analysis: Educatial tutorial.]. Kyiv, 404 p.[in Ukrainian].

5. Klymeniuk, M.M. \& Kacharian, I.S. (2011). Stratehiia upravlinnia vyshchym navchalnym zakladom $v$ suchasnykh umovakh [Management strategy of higher education institution in modern conditions]. Kyiv, 192 p. [in Ukrainian]. 
6. Lesechko, M.D. \& Rudnytska, R.M. (2004). Stratehichne planuvannia: navchalnyi posibnyk [Strategic Planning: A Tutorial]. Lviv, 76 p. [in Ukrainian].

7. Natroshvili, S.H. (2015). Stratehichne upravlinnia vyshchym navchalnym zakladom: teoriia, metodolohiia, praktyka: monohrafiia [Strategic Management of Higher Education: Theory, Methodology, Practice: Monograph]. Kyiv, 326 p. [in Ukrainian].

8. Riding, K. (2005). Strategicheskoe biznesplanirovanie: Dinamicheskaya sistema povysheniya effektivnosti i obespecheniya konkurentnogo preimushchestva [Strategic business planning: A dynamic system to increase efficiency and provide a competitive advantage]. (Ed.). I.A. Voytyuk. Dnepropetrovsk, 384 p. [in Russian].

9. Svystovych, M.B. Sutnist i osnovni poniattia stratehichnoho planuvannia [The essence and basic concepts of strategic planning]. Available at: http:// academy.gov.ua/ej/ej18/PDF/06.pdf [in Ukrainian].

10. Ackoff, R. (1970).Concept of Corporate Planning. New York:Wiley, p.1. [in English].

11. Grang-Chol CHANG Strategic Planning in Education: Some Concept and Methods Vendredi 4 juillet 2008. Available at: http://www.iiep.unesco.org/. [in English].

Стаття надійшла до редакції 27.09.2019

DOI:

Світлана Шумовецька, кандидат педагогічних наук, доцент кафедри педагогіки та соиіально-економічних дисииплін Національної академії Державної прикордонної служби імені Б. Хмельницького

\section{ПЕДАГОГІЧНІ УМОВИ ФОРМУВАННЯ ПРОФЕСІЙНОЇ КУЛЬТУРИ МАЙБУТНІХ ОФІЦЕРІВ-ПРИКОРДОННИКІВ: ВИКОРИСТАННЯ ПОТЕНЦІАЛУ ПРОБЛЕМНИХ МЕТОДІВ}

У статті розкрито значення проблемних методів для формування професійної культури майбутніх офічерів-прикордонників. Наведено приклади використання проблемних методів під час викладання навчальної дисиипліни "Історія війн, конфліктів та охорони державного кордону", насамперед ситуації конфлікту, проблемні завдання, щзо потребують з'ясування причин та наслідків подій, узагальнення, систематизачії чи спростування. Доведено, що використання проблемних методів навчання стимулюватиме розвиток пізнавальної активності майбутніх офіџерів-прикордонників, допоможе вчити їх бачити проблеми та визначати шляхи їх розв 'язання, дозволить формувати їх характер й розуміння моральної відповідальності, необхідності долати труднощі.

Ключові слова: професійна культура; офіцер-прикордонник; педагогічні умови; курсанти; проблемні методи; проблемні ситуаиіiі.

Лim. 8.

Svitlana Shumovetska, Ph.D.(Pedagogy), Associate Professor of the Pedagogy and SocioEconomic Sciences Department National Academy of the State Border Service named after Bohdan Khmelnytskiy

\section{PEDAGOGICALCONDITIONS OF FORMATION THE PROFESSIONAL CULTURE OF FUTURE FRONTIER OFFICERS: USE OF THE POTENTIAL OF PROBLEM METHODS}

The advantages and importance of problematic methods for formation the professional culture of future frontier officers have been revealed in the article. Problematic methods are evidence of non-directive pedagogy, that is, one that prioritizes the active role of the individual in the acquisition of knowledge and the acquisition of professional skills. It has been suggested to present problem situations in the form of various professional tasks, consecutive problem situations, which must necessarily contain some contradiction, which requires their analysis, formulation of problems and their solving. The methodological value of the problematic method is that the cadets master their professional knowledge more intensively, solve problems, rather than listen to the teacher passively. Through problem-based training, teachers can create the necessary conditions for independent decision-making, comparison of different behavioral options, change of orientation in training from gaining to acquisition of knowledge, from passive consumption to active analysis. Advantages of problem-based methods of training are high level of independence of cadets, intensification of their mental activity.

Examples of the use of problematic methods in teaching the subject of History of Wars, Conflicts and State 